\title{
Infectious Risk of the Hospital Environment in the Center of Morocco: A Case of Care Unit Surfaces
}

\author{
Samira Jaouhar $\left(\mathbb{D},{ }^{1,2}\right.$ Abdelhakim El Ouali Lalami $\mathbb{D}^{2},{ }^{2}$ Khadija Ouarrak $\left(\mathbb{D},{ }^{3}\right.$ \\ Jawad Bouzid $\mathbb{D},{ }^{4}$ Mohammed Maoulouaa $\mathbb{D}^{3},{ }^{3}$ and Khadija Bekhti $\mathbb{D D}^{1}$ \\ ${ }^{1}$ Laboratory of Microbial Biotechnology, Faculty of Science and Technology, Sidi Mohammed Ben Abdellah University Fez, \\ Morocco \\ ${ }^{2}$ Higher Institute of Nursing and Health Professions, Fez, Morocco \\ ${ }^{3}$ Medical Analysis Laboratory of the Meknes Hospital Center, Regional Health Department Fez-Meknes, Fez, Morocco \\ ${ }^{4}$ Laboratory of Health Sciences and Technologies, Higher Institute of Health Sciences, Hassan First University, Settat, Morocco \\ Correspondence should be addressed to Jawad Bouzid; jawad.bouzid@uhp.ac.ma
}

Received 4 February 2020; Accepted 15 April 2020; Published 26 May 2020

Academic Editor: Joaquim Ruiz

Copyright (c) 2020 Samira Jaouhar et al. This is an open access article distributed under the Creative Commons Attribution License, which permits unrestricted use, distribution, and reproduction in any medium, provided the original work is properly cited.

\begin{abstract}
Background. Equipment and hospital surfaces constitute a microbial reservoir that can contaminate hospital users and thus create an infectious risk. The aim of this work, which was carried out for the first time at a hospital in Meknes (regional hospital in the center of Morocco), is to evaluate the microbiological quality of surfaces and equipment in three potential risk areas (burn unit, operating room, and sterilization service). Methods. This study was carried out over a period of 4 months (February-May 2017). A total of 60 samples were taken by swabbing according to the standard (ISO/DIS 14698-1 (2004)) in an environment of dry area and equipment after biocleaning. Isolation and identification were performed according to conventional bacteriological methods and by microscopic observation for fungi. Results. The study showed that $40 \%$ of surface samples were contaminated after biocleaning. The burn unit recorded a percentage of $70 \%$ contamination ( $p$ value $<0.001$ ), $13 \%$ for the sterilization service, and $7 \%$ for the operating room. $89 \%$ of the isolates were identified as Gram-positive bacteria against $11 \%$ for fungi $(p$ value $<0.001)$. Bacterial identification showed coagulase-negative staphylococci (32\%), Bacillus spp. (16\%), Corynebacterium (8\%), and oxidase-negative Gram-positive bacillus (40\%) while fungal identification showed Aspergillus niger $(n=2)$ and Aspergillus nidulans ( $n=1$ ). Conclusion. To control the infectious risk related to equipment and hospital surfaces, it would be necessary to evaluate the disinfection protocol applied in these units.
\end{abstract}

\section{Introduction}

Healthcare-associated infections (HAIs) represent a serious public health problem as they lead to increased mortality, morbidity, and costs for patients, their families, and health systems $[1,2]$. According to the World Health Organization (WHO), HAIs affect 5 to $10 \%$ of patients in developed countries [3]. In developed countries, they affect $25 \%$ of hospitalized patients [2]. In the Mediterranean region, the prevalence of HAIs has been $10.5 \%$ [1]. In Morocco, the prevalence was $17.8 \%$ in a University Hospital (UH) in Rabat (2007) [4], 10.3\% (UH Rabat, 2010) [5], and 6.7\% (UH Fez,
2007) [6]. In the city of Meknes, a study conducted in 2013 at Mohammed V Hospital revealed that the prevalence of HAI was 9.4\% [7]. The microorganisms responsible for HAI were Escherichia coli, Klebsiella pneumoniae, Staphylococcus aureus, and Pseudomonas aeruginosa $[1,6]$. The services most affected by HAI were the services of surgery, medicine, pediatrics, intensive care, obstetric gynecology, burns unit, and trauma service [7-9]. The factors responsible for HAI are patients (age and immune status), medical practices, and hospital environment (air, surfaces, and water) [10]. The hospital environment is a reservoir of pathogens from patients or the hands of caregivers [11] or the environment 
[12]. Weber et al. [13] reported that $20 \%$ to $40 \%$ of HAIs have been attributed to cross-infection via the hands of care staff, which have become contaminated from contact with the patient or by touching contaminated environmental surfaces. The role of the environment in the emergence of HAI has been demonstrated by several studies [14-16]. Thus, it is clear that biomonitoring of the hospital environment is an essential element in the control and prevention of HAI. Biomonitoring provides the information to reduce and prevent the exposure of populations to contaminants in the environment [17]. Microbiological monitoring of the clinical environment, especially surfaces and medical equipment, can be used to detect the presence of nosocomial pathogens and also to evaluate the efficacy of routine cleaning/disinfection practices [18], while the assessments of hospital hygiene indicate that routine cleaning and disinfection may not be performed efficiently and may not be sufficient to eliminate nosocomial pathogens $[19,20]$. Many types of nosocomial microorganisms have been found in medical devices and hospital surfaces such as Clostridium difficile [21], Klebsiella pneumoniae [15, 22], Staphylococcus aureus [21, 23], coagulase-negative staphylococci [22-24], and Acinetobacter baumannii $[13,14]$. So, the aim of our study was (i) to estimate bacterial contamination of medical devices and hospital surfaces and also (ii) to examine the presence of specific nosocomial pathogens in three services with potential risk for patients and care staff (burn unit, operating room, and sterilization service). This investigation was conducted in a hospital with a regional vocation in Meknes (center of Morocco). The results of this study will help the nosocomial infection control committee (NICC) to make a risk analysis strategy to control the risk related to the hospital surface.

\section{Materials and Methods}

2.1. Study Site. We carried over a period of 4 months (February-May 2017) the samples from surfaces and medical devices used in three services in a hospital at Meknes (Morocco): burn unit, operating room, and sterilization service. The choice of burn unit was based on the fact that patients hospitalized are immunocompromised and on the result of a study that showed the predominance of clinical bacteria in this service [25]. The choice of other services was based on the French standard (FS S 90 351-2013) [26].

2.2. Sampling Technique. The microbiological sampling of the surfaces was carried out by the swabbing technique as recommended by the standard ISO 14698-1 (2004) [27]. Sampling by swabbing technique has been used by several studies that have looked for the presence of nosocomial germs of interest [18]. Cotton swab premoistened in a buffer solution was used for sampling surfaces. At each site, an area of approximately $25 \mathrm{~cm}^{2}$ was swabbed and repeated striations in two directions at right angles to each other was carried out in a close zigzag pattern while rotating the swab during sampling of surface ISO 14698-1 (2004) [27]. Then, the swab was wetted in tubes containing Brain Heart
Infusion (BHI) broth [28]. The collected samples were transported immediately to the medical laboratory of Mohammed V Hospital and incubated for 24 to $48 \mathrm{~h}$ at $37^{\circ} \mathrm{C}$. The sampling of each site was repeated three times in order to have a representative result. The Coordination Center of the Committee for the Control of Nosocomial Infections (CCNI) Sud-Ouest (2016) [26] recommends taking samples in these three services, excluding human activity and after biocleaning, except for sterilization where samples taken can be carried out in activity. The selected sampling points are those that may represent a health risk to patients or staff.

2.3. Analysis of Samples. Using swabs, we have seeded the suspension on a Petri dish containing the PCA (Plate Count Agar) for the enumeration of microorganisms. Then, the Petri dishes were incubated at $37^{\circ} \mathrm{C}$ for $24 \mathrm{~h}$ to 48 hours. After $24 \mathrm{~h}$ of incubation, a number of colonies were noted (the number of colonies was presented in colony-forming unit $(\mathrm{CFU}) / 25 \mathrm{~cm}^{2}$ ).

For isolation, a volume of $10 \mu \mathrm{L}$ of each sample was inoculated on semiselective media: MacConkey (Enterobacteriaceae), Chapman (staphylococci and micrococci), Cetrimide agar (Pseudomonas aeruginosa), and Sabouraud (fungi). The Petri dishes of bacteria were incubated for 24 hours, as for the fungi for 5 to 7 days. The identification of bacteria was carried out according to conventional bacteriology methods. Fungi (molds) were identified by two fundamental examinations: macroscopic and microscopic [29].

2.4. Data Processing and Analysis. Data entry was done using Microsoft Office Excel 2010. The descriptive and analytical parts were realized using the XLSTAT extension. To give meaning to the results, we used the chi-square test; the $p$ value $<0.001, p$ value $<0.01$, and $p$ value $<0.05$ were considered highly significant, very significant, and significant, respectively.

\section{Results}

Table 1 shows that autoclave, bedrails, bedside tables, and operating tables are the most contaminated sites with values exceeding the limits of acceptability in the services studied.

From a total of 60 samples, $40 \%(n=24)$ of the samples analyzed were found to be positive and 60\% $(n=36)$ were found to be negative. The burn unit (BU) department recorded a very high percentage $(70 \%)$, followed by the sterilization room (S) with a percentage of $13 \%$ and finally the operating room with a percentage of $7 \%$ (Figure 1 ). The distribution of positivity by service is highly significant (chisquared $=22.639, d f=2, p$ value $<0.001)$.

The fungal flora is present in two departments, $67 \%$ $(n=2)$ of the molds were found in the BU, whereas only $33 \%$ $(n=1)$ of the samples showed the presence of the fungal flora in the sterilization room (SR). A percentage of $89 \%(n=25)$ of the isolates were bacteria, while fungi accounted for only $11 \%(n=3)$. The distribution of the positive samples according to the germs is highly significant (chisquare $=17.286, d f=1, p$ value $<0.001)$. Bacterial identification revealed that all bacteria are Gram-positive. 
TABLE 1: CFU/25 $\mathrm{cm}^{2}$ found in the different critical points of the three services studied.

\begin{tabular}{|c|c|c|c|}
\hline & Services & Critical points & $\mathrm{CFU} / 25 \mathrm{~cm}^{2}(M \pm \sigma)$ \\
\hline \multirow{10}{*}{ Burn unit } & \multirow{3}{*}{ Operating room } & Operating table & 0 \\
\hline & & Instruments table & 0 \\
\hline & & Anesthesia mask & 0 \\
\hline & \multirow{4}{*}{ Patient's room 1} & Cart & $3 \pm 1.67$ \\
\hline & & Bed rails & $5 \pm 4.67$ \\
\hline & & Bedside tables & $8 \pm 6.67$ \\
\hline & & Refrigerator & $7 \pm 4.33$ \\
\hline & \multirow{3}{*}{ Patient's room 2} & Cart & $41 \pm 25.33$ \\
\hline & & Bedside tables & $87 \pm 47.33$ \\
\hline & & Bed rails & $173 \pm 100$ \\
\hline \multirow{5}{*}{ Operating room } & Operating table & $58 \pm 33.33$ & \\
\hline & Instruments table & 0 & \\
\hline & Anesthesia table & 0 & \\
\hline & Mask of anesthesia & 0 & \\
\hline & Scialytic & 0 & \\
\hline \multirow{5}{*}{ Sterilization } & \multirow{2}{*}{ Conditioning area } & Paillasse & 0 \\
\hline & & Autoclave & $115 \pm 66.67$ \\
\hline & \multirow{3}{*}{ Storage area } & Cart & 0 \\
\hline & & Paillasse (1) & 0 \\
\hline & & Paillasse (2) & $1 \pm 0, .3$ \\
\hline
\end{tabular}

$M \pm \sigma$ : mean \pm standard deviations. CFU: colony-forming unit.

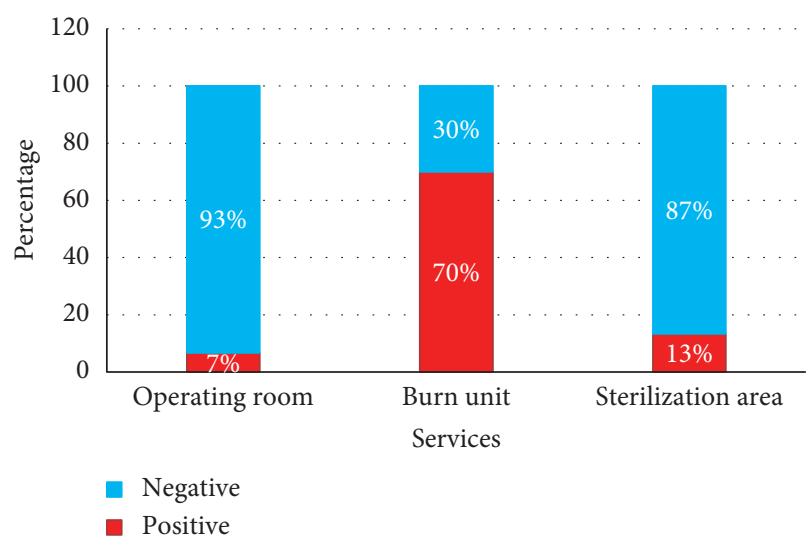

FIgURe 1: Percentage of contamination by services.

They are distributed as follows: $32 \%(n=8)$ of Grampositive cocci were identified as coagulase-negative staphylococci, of which $8 \%$ were identified as Staphylococcus epidermidis and 4\% were Staphylococcus saprophyticus, $16 \%$ of bacteria $(n=4)$ were identified as Bacillus spp., while Corynebacterium spp. were identified with a percentage of $8 \%(n=2)$, and finally, $40 \%$ of Gram-positive bacillus were unidentifiable $(n=10)$ (Figure 2).

The bacterial distribution is statistically very significant (chi-square $=17.28, d f=2, p$ value $<0.01$ ). From the isolates, only 11 strains have a nosocomial interest: 8 coagulasenegative staphylococci and 3 Aspergillus spp. Fungal floras include Aspergillus niger $(n=2)$ (Figure 3) and Aspergillus nidulans $(n=1)$ (Figure 4$)$.

\section{Discussion}

The hospital environment, especially surfaces, is generally colonized by many opportunistic and pathogenic microorganisms. The surfaces are contaminated by

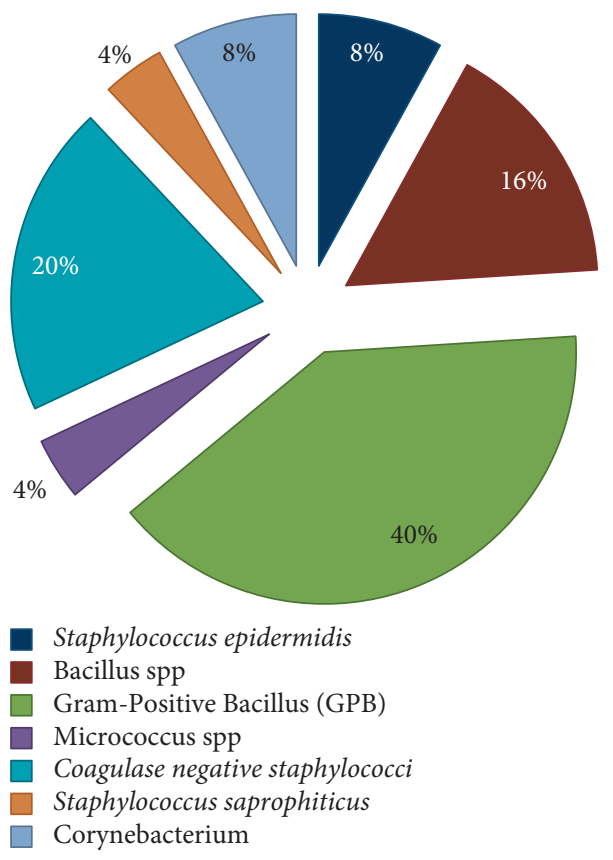

FIGURE 2: Distribution of isolated bacteria.

microorganisms derived from the patient himself or sedimentation of particles in the air [30]. Several pathogens can survive for days and months in dry surface and also can be considered as the source of HAI [31]. The role of the environment in the development of HAI was poorly documented except for environmental microorganisms (Aspergillosis, Legionellosis) [32].

Nevertheless, studies have shown this relationship $[14,15]$. Microbiological surface checks are necessary to prevent and limit the transmission of microbiological risks between the environment and humans. Our study showed 


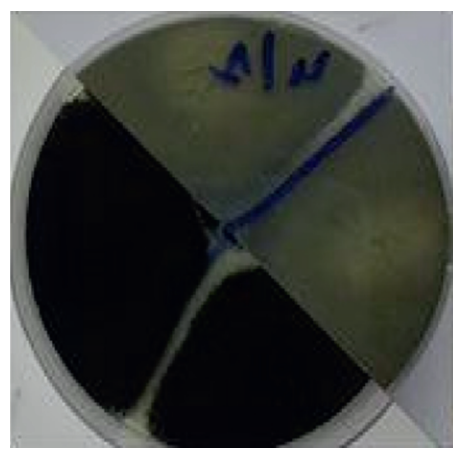

(a)

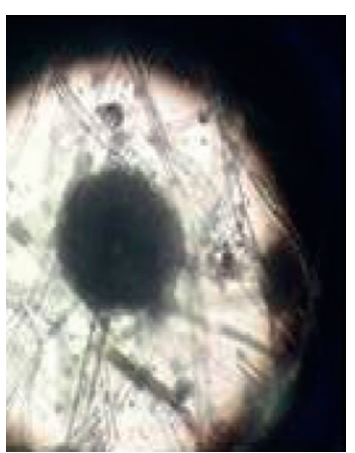

(b)

FIGURE 3: Aspergillus niger found in the sterilization service (storage area).

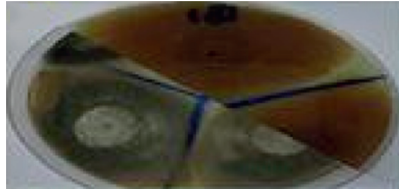

(a)

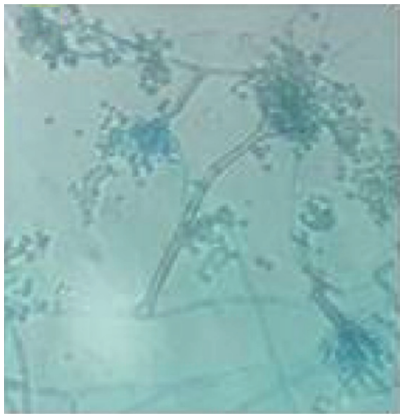

(b)

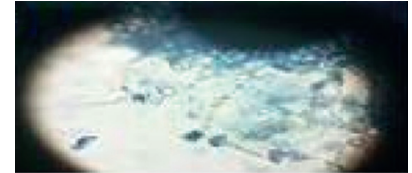

(c)

FIgure 4: Aspergillus nidulans found in burn unit.

that $40 \%$ of the samples were found positive. The burn unit was the most concerned area with very high contamination (70\%), followed by the sterilization service (13\%) and only $7 \%$ for the operating room. A study conducted at a hospital in $\mathrm{Fez}$ (Morocco) reported a preponderance of bacterial strains as an emergency operating room and operating room [24]. Moreover, the contamination of the operating room has also been demonstrated by Saouide el Ayne et al. [33]. The most contaminated sites were autoclave, bedrails, bedside tables, and operating tables. Several studies have shown that the most contaminated sites are those that are in frequent contact with caregivers and patients [34, 35]. Meunier et al. also reported and observed severe contamination of hospital surfaces where they found that the medical devices and surface close to patients are largely covered by pathogen microorganisms [28].

The total microorganisms count in the sterilization service showed that the acceptability limits were exceeded $\left(\mathrm{CFU} / 25 \mathrm{~cm}^{2}>30\right)$ [26]. We also found that the limit values were exceeded in the patient's room (burn unit) and the operating room $\left(\mathrm{CFU} / 25 \mathrm{~m}^{2}>10\right)$ according to the Association for the Prevention and Contamination Study (APCS).

In this study, bacteria represent $89 \%$ of isolates against $11 \%$ for fungi. Several studies have reported contamination of the hospital environment with fungi [36, 37].
Identification of fungi revealed the presence of Aspergillus niger (sterilization service and patient's room) and Aspergillus nidulans (patient's room). This result requires a review of hygiene procedures in these services [26]. Infections due to Aspergillus spp. result in significant mortality and morbidity. Aspergillus niger has been associated with pulmonary disease [38], cutaneous infections [39], and otomycosis [40].

Our result showed the presence of only Gram-positive bacteria. Other studies have shown the presence of Grampositive bacteria and Gram-negative bacteria [24, 37, 41]. Another study has shown that Gram-positive bacteria can survive in dry environments for longer periods than Gramnegative bacteria [42]. This result could be explained by the desiccation resistance of Gram-positive versus Gram-negative bacteria [43]. Bacterial identification determined coagulasenegative staphylococci at 32\%, Bacillus spp. at 16\%, and Corynebacterium spp. at $8 \%$. The medical devices of the Iranian hospitals were colonized by coagulase-negative staphylococci [22]. The results of our study are consistent with those found in El Idrissi Hospital in Kenitra [33]. Surveillance of the microbiological quality of surfaces and equipment carried out at two hospitals in Morocco showed the presence of coagulase-negative staphylococci [14] and Bacillus spp. [24, 37]. Meunier et al. reported that Bacillus spp. bacteria are constantly present in the environment and do not appear to be accessible to biocleaning, and this could be explained by their ability to sporulate [28]. 
The presence of these bacteria in the patient's immediate environment can cause infectious diseases. Indeed, coagulasenegative staphylococci are recognized as a cause of nosocomial infections [44] including endocarditic for immunocompromised patients [45]. Microorganisms found on surfaces depend on several factors: (i) human activity, which results in a supply of microorganisms by patients and staff [46], and (ii) the quality of biocleaning and characteristics of microorganisms (adhesion to inert surfaces, ability to produce a biofilm, etc.) [47]. High contamination and the presence of microorganisms of human and environmental origin in medical devices and surfaces could be linked, on the one hand, to inefficiency disinfectants and, on the other hand, poor hygiene and inappropriate application cleaning procedures.

The results of our study showed that the surfaces and medical devices of the services studied are colonized by pathogens that could cause HAI. These infections can be reduced by appropriate hand hygiene [48] and appropriate disinfection of surfaces and medical devices [2]. In recent years, a number of studies have demonstrated that environmental disinfection and cleaning interventions can reduce HAI [49, 50]. Notably, Datta et al. [51] and Grabsch et al. [52] demonstrated that methicillin-resistant Staphylococcus aureus acquisition and vancomycin-resistant Enterococcus were reduced by disinfection intervention to the rooms previously occupied by patients colonized by the same pathogen. This study raises the question of the effectiveness of the disinfectants used in these services.

\section{Conclusion}

This study made it possible to know the microbial ecology of the three services at potential risk (burn unit, operating room, and sterilization service). The identification revealed the exclusive presence of Gram-positive bacteria with a preponderance of coagulase-negative staphylococci and the presence of fungal agents of Aspergillus niger and Aspergillus nidulans. To control the infectious risk related to the environment hospital, especially the surfaces, it would be necessary to evaluate the disinfection protocol applied to the surfaces.

\section{Data Availability}

Data used to support the findings of this study are included within the article and also available from the corresponding author upon request.

\section{Conflicts of Interest}

The authors declare that they have no conflicts of interest.

\section{Authors' Contributions}

S. J. analyzed the data and drafted the manuscript. K. O. and M. M. supervised the field activities and interpreted the data. J. B. conducted the data analysis and interpreted the data. A. E. L. and K. B. contributed to the conception and design of the study and helped in writing the manuscript. All authors read and approved the final manuscript.

\section{Acknowledgments}

The authors express special gratitude to the staff of Mohamed V Hospital Laboratory (Meknes) for their collaboration.

\section{References}

[1] K. Amazian, J. Rossello, A. Castella et al., "Prevalence of nosocomial infections in 27 hospitals in the Mediterranean region," Eastern Mediterranean Health Journal, vol. 16, no. 10, pp. 1070-1078, 2010.

[2] Organisation Mondiale de la Santé, WHO Guidelines on Hand Hygiene in Health Care: A Summary. First Global Patient Safety Challenge Clean Care Is Safer Care, Organisation Mondiale de la Santé, Geneva, Switzerland, 2019, https:// www.who.int/gpsc/5may/tools/who_guidelineshandhygiene_summary.pdf.

[3] Organisation Mondiale de la Santé, Pourquoi un Défi Mondial Sur les Infections Nosocomiales, Organisation Mondiale de la Santé, Geneva, Switzerland, 2018, http://www.who.int/gpsc/ background/fr/.

[4] I. Jrondi, I. Khoudri, A. Azzouzi et al., "Prevalence of hospitalacquired infection in a Moroccan university hospital," American Journal of Infection Control, vol. 35, no. 6, pp. 412-416, 2007.

[5] R. Razine, A. Azzouzi, A. Barkat et al., "Prevalence of hospitalacquired infections in the university medical center of Rabat, Morocco," International Archives of Medicine, vol. 5, no. 1, p. 26, 2012.

[6] K. EL Rhazi, S. El Fakir, M. Berraho et al., "Prévalence et facteurs de risque des infections nosocomiales au CHU hassan II de Fès (maroc)," Eastern Mediterranean Health Journal, vol. 13, no. 1, pp. 56-63, 2007.

[7] M. Khouchoua, Enquête de Prévalence des Infections Associées aux Soins au Centre Hospitalier Régional Mohamed V Meknès, Ecole Nationale de Santé Publique, Rabat, Morocco, 2018.

[8] M. Andrianarivelo, N. E. Rafaravavy, C. Rafalimanana, T. N. Andriantahiana, and L. Robinson, "Profil bactériologique des infections néonatales à l'unité de réanimation néonatale de la maternité de befelatanana," Revue d'Anesthésie-Réanimation Et de Médecine d'Urgence, vol. 2, no. 2, pp. 1-4, 2010.

[9] A. Chaibdraa and M. C. Bentakouk, "Etude bactériologique sur 30 mois dans un service de brulés," Ann Burns Fire Disasters, vol. 21, no. 1, pp. 7-12, 2008.

[10] Ministère de la Santé Marocaine, Manuel d'Hygiène Hospitalière et de Prévention des Infections Nosocomiales, Ministère de la Santé Marocaine, Rabat, Morocco, 2008.

[11] A.-P. Sergent, C. Slekovec, J. Pauchot et al., "Bacterial contamination of the hospital environment during wound dressing change," Orthopaedics \& Traumatology: Surgery \& Research, vol. 98, no. 4, pp. 441-445, 2012.

[12] W. A. Rutala and D. J. Weber, "Water as a reservoir of nosocomial pathogens," Infection Control and Hospital Epidemiology, vol. 18, no. 9, pp. 609-616, 1997.

[13] D. J. Weber, W. A. Rutala, M. B. Miller, K. Huslage, and E. Sickbert-Bennett, "Role of hospital surfaces in the transmission of emerging healthcare-associated pathogens: norovirus, Clostridium difficile, and acinetobacter species," American Journal of Infection Control, vol. 38, no. 5, pp. S25-S33, 2010.

[14] W. Bouguenoun, S. Bakour, A. A. Bentorki, C. Al Bayssari, T. Merad, and J.-M. Rolain, "Molecular epidemiology of 
environmental and clinical carbapenemase-producing gramnegative bacilli from hospitals in guelma, Algeria: multiple genetic lineages and first report of OXA-48 in Enterobacter cloacae," Journal of Global Antimicrobial Resistance, vol. 7, pp. 135-140, 2016.

[15] S. Natoub, A. Barguigua, S. B. Zriouil et al., "Incidence of extended-spectrum be-ta-lactamase-producing Klebsiella pneumoniae among patients and in the environment of hassan II hospital, settat, Morocco," Advances in Microbiology, vol. 6, no. 3, pp. 152-161, 2016.

[16] J. M. Boyce, "Environmental contamination makes an important contribution to hospital infection," Journal of Hospital Infection, vol. 65, no. 2, pp. 50-54, 2007.

[17] R. Morello-Frosch, J. G. Brody, P. Brown, R. G. Altman, R. A. Rudel, and C. Et Pérez, "Toxic ignorance and right-toknow in biomonitoring results communication: a survey of scientists and study participants," Environmental Health, vol. 8, no. 6, 2009.

[18] S. Galvin, A. Dolan, O. Cahill, S. Daniels, and H. Humphreys, "Microbial monitoring of the hospital environment: why and how?" Journal of Hospital Infection, vol. 82, no. 3, pp. 143-151, 2012.

[19] P. C. Carling, J. Briggs, D. Hylander, and J. Perkins, “An evaluation of patient area cleaning in 3 hospitals using a novel targeting methodology," American Journal of Infection Control, vol. 34, no. 8, pp. 513-519, 2006.

[20] F. A. Manian, S. Griesenauer, D. Senkel et al., "Isolation of Acinetobacter baumannii complex and methicillin-resistant Staphylococcus aureus from hospital rooms following terminal cleaning and disinfection: can we do better?" Infection Control \& Hospital Epidemiology, vol. 32, no. 7, pp. 667-672, 2011.

[21] A. Vandini, R. Temmerman, A. Frabetti et al., "Hard surface biocontrol in hospitals using microbial-based cleaning products," PLoS One, vol. 9, no. 9, Article ID e108598, 2014.

[22] A. Ekrami, A. Kayedani, M. Jahangir, E. Kalantar, and M. Jalali, "Isolation of common aerobic bacterial pathogens from the environment of seven hospitals, Ahvaz, Iran," Jundishapur Journal of Microbiology, vol. 4, no. 2, pp. 75-82, 2011.

[23] B. Oumokhtar, A. El Ouali Lalami, N. Benaicha, B. Arhoune, and W. Bono, "Environmental surfaces in healthcare setting: a great potential risk of pathogens transmission," Biomedical Research, vol. 28, no. 6, pp. 2398-2401, 2017.

[24] A. El Ouali Lalami, H. Touijer, F. El-Akhal et al., "Microbiological monitoring of environment surfaces in a hospital in Fez city, Morocco," Journal of Materials and Environmental Science, vol. 7, no. 1, pp. 123-130, 2016.

[25] S. Jaouhar, K. Bekhti, M. Maoulouaa et al., "Management of the monitoring of the hospital environment: microbial profile of the services of a regional hospital in the city of meknes in central Morocco," Journal of Pharmaceutical Sciences and Research, vol. 11, no. 6, pp. 2445-2451, 2019.

[26] Ministry of Social Affairs and Health, Surveillance Microbiologique de L'environnement dans Établissements de Santé-Air, eau et Surfaces, Ministry of Social Affairs and Health, 2016, http://nosobase.chu-lyon.fr/recommandations/ cclin_arlin/cclinSudOuest/2016_Surv_microbio_ environnement_CCLIN.pdf.

[27] Norme ISO 14698-1, "Salles propres et environnement apparentés-maîtrise de la bio-contamination-AFNOR,” 2004.

[28] O. Meunier, C. Hernandez, M. Piroird, R. Heilig, D. Steinbach, and A. Freyd, "Prélèvements bactériologiques des surfaces: importance de l'étape d'enrichissement et du choix des milieux de culture," Annales de Biologie Clinique, vol. 63, no. 5, pp. 481-486, 2005.
[29] P. Dufresne and S. G. Guy, Identification des Champignons D’importance Médicale, Institut National de Santé Publique du Québec, Quebec, Canada, 2018, https://www.inspq.qc.ca/ sites/default/files/lspq/identification_champignons_ importance_medicale.pdf.

[30] F. Barbut and D. Neyme, "Les difficultés d'interprétation des contrôles microbiologiques environnementaux," Revue Francophone des Laboratoires, vol. 382, pp. 27-32, 2006.

[31] A. Kramer, I. Schwebke, and G. Kampf, "How long do nosocomial pathogens persist on inanimate surfaces a systematic review," BMC Infectious Diseases, vol. 6, no. 1, pp. 1-8, 2006.

[32] C. Alberti, A. Bouakline, P. Ribaud et al., "Relationship between environmental fungal contamination and the incidence of invasive aspergillosis in haematology patients," Journal of Hospital Infection, vol. 48, no. 3, pp. 198-206, 2001.

[33] N. Saouide el Ayne, A. Echchelh, A. Chaouch, N. Auajjar, S. Hamama, and A. Soulaymani, "Rôle de l'environnement hospitalier dans la prévention des infections nosocomiales: surveillance de la flore des surfaces à l'hôpital el idrissi de kenitra-maroc," European Scientific Journal, vol. 10, no. 9, pp. $238-247,2014$.

[34] S. Méité, C. Boni-Cissé, P. Monemo, A. P. Mlan Tanoa, H. Faye-Ketté, and H. Dosso, "Surveillance microbiologique des surfaces au niveau d'un établissement hospitalier de niveau tertiaire: exemple du chu de yopougon, abidjan, Cote d'Ivoire," Journal of Pharmaceutical and Biological Sciences, vol. 11, no. 1, pp. 73-81, 2010.

[35] L. S. Munoz-Price, D. J. Birnbach, D. A. Lubarsky et al., "Decreasing operating room environmental pathogen contamination through him proved cleaning practice," Infection Control \& Hospital Epidemiology, vol. 33, no. 9, pp. 897-904, 2002.

[36] F. Derouin, C. Alberti, A. Bouakline, C. Lacroix, and P. Ribaud, "Corrélation entre la contamination fongique de l'environnement hospitalier et le risque d'aspergillose invasive nosocomiale," La Lettre de l'Infectiologue, vol. 17, no. 2, pp. 29-34, 2002.

[37] S. Berrada, G. B. Touimi, L. Bennani et al., "Exploration microbiologique des surfaces d'un centre d'hémodialyse de la ville de Fès: étude descriptive transversale," Revue Francophone Internationale de Recherche Infirmière, vol. 3, no. 2, pp. 120-128, 2017.

[38] A. K. Person, S. M. Chudgar, B. L. Norton, B. C. Tong, and J. E. Stout, "Aspergillus niger: an unusual cause of invasive pulmonary aspergillosis," Journal of Medical Microbiology, vol. 59, no. 7, pp. 834-838, 2010.

[39] K. W. Loudon, A. P. Coke, J. P. Burnie, A. J. Shaw, B. A. Oppenheim, and C. Q. Morris, "Kitchens as a source of Aspergillus niger infection," Journal of Hospital Infection, vol. 32, no. 3, pp. 191-198, 1996.

[40] J. Araiza, P. Canseco, and A. Bonifaz, "Otomycosis: clinical and mycological study of 97 cases," Revue de Laryngologie-Otologie-Rhinologie, vol. 127, pp. 251-254, 2006.

[41] S. W. Lemmen, H. Häfner, D. Zolldann, S. Stanzel, and R. Lütticken, "Distribution of multi-resistant gram-negative versus gram-positive bacteria in the hospital inanimate environment," Journal of Hospital Infection, vol. 56, no. 3, pp. 191-197, 2004.

[42] Y. Hirai, "Survival of bacteria under dry conditions; from a viewpoint of nosocomial infection," Journal of Hospital Infection, vol. 19, no. 3, pp. 191-200, 1991. 
[43] A. Schmitt, N. Glasser, D. Steinbach, and O. Meunier, "Études expérimentales de l'effet rémanent d'un détergent désinfectant pour surfaces sur une souche d'Escherichia coli," Pathologie Biologie, vol. 57, no. 6, pp. 463-469, 2009.

[44] F. Barbier, "Staphylocoques à coagulase négative: quand, comment et pourquoi sont-ils responsables d'infections?" Journal des Anti-Infectieux, vol. 17, no. 1, pp. 15-19, 2015.

[45] V. H. Chu, C. W. Woods, J. M. Miro et al., "Emergence of coagulase-negative staphylococci as a cause of native valve endocarditis," Clinical Infectious Diseases, vol. 46, no. 2, pp. 232-242, 2008.

[46] M. Mora, A. Mahnert, K. Koskinen et al., "Microorganisms in confined habitats: microbial monitoring and control of intensive care units, operating rooms, clean rooms and the international space station," Frontiers in Microbiology, vol. 7, p. 1573, 2016.

[47] R. M. Donlan, "Biofilms: microbial life on surfaces," Emerging Infectious Diseases, vol. 8, no. 9, pp. 881-890, 2002.

[48] A. Al Kadi and S. A. Salati, "Hand hygiene practices among medical students," Interdisciplinary Perspectives on Infectious Diseases, vol. 6, 2012.

[49] J. Curtis and M. D. Donskey, "Does improving surface cleaning and disinfection reduce health care-associated infections?" American Journal of Infection Control, vol. 41, no. 5, pp. S12-S19, 2013.

[50] J. H. Han, N. Sullivan, B. F. Leas, D. A. Pegues, J. L. Kaczmarek, and C. A. Umscheid, "Cleaning hospital room surfaces to prevent health care-associated infections," Annals of Internal Medicine, vol. 163, no. 8, pp. 598-380, 2015.

[51] R. Datta, R. Platt, D. S. Yokoe, and S. S. Huang, "Environmental cleaning intervention and risk of acquiring multidrugresistant organisms from prior room occupants," Archives of Internal Medicine, vol. 171, no. 6, pp. 491-494, 2011.

[52] E. A. Grabsch, A. A. Mahony, D. R. M. Cameron et al., "Significant reduction in vancomycin-resistant Enterococcus colonization and bacteraemia after introduction of a bleachbased cleaning-disinfection programme," Journal of Hospital Infection, vol. 82, no. 4, pp. 234-242, 2012. 